\title{
Comparing Monetary And Fiscal Policy Transmission Across The Americas And The Emu-Area
}

Dimitrios Tsoukalas, Purdue University-Calumet, USA

\begin{abstract}
This paper estimates structural VAR models to compare the transmission mechanism of monetary and fiscal policy in the Americas and the EMU-area countries. First, the NAFTA countries are considered and the estimation results are compared with those for the EMU-area countries. Attention is also paid to interaction of macroeconomic policies and the effects of shocks in financial markets. Results show that the Americas except for the U.S. and Canada react rather differently to monetary and fiscal policy shocks than the EMU-area countries.
\end{abstract}

Keywords: EMU-area, SVA, transmission mechanism, monetary, fiscal policy

\section{INTRODUCTION}

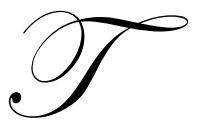

he relationship between fiscal and monetary policies in monetary unions has been the object of many studies in recent years. Much of this is a reaction to the Maastrict Treaty of 1992 and the Pact for Stability and Growth (SGP), adopted by the EU-Council 1997. The Treaty institutionalized binding fiscal rules for monetary convergence; the Pact specified these rules and empowers the Council to impose sanctions for non-compliance as a non-interest bearing deposit (maximum $0.5 \%$ of GDP) which is converted into affine after two years, unless the excessive deficit has been corrected. The European Monetary Union (EMU), the largest historical experiment in giving up sovereignty in monetary (and other) policy areas, has captured the imagination of policy makers and researchers alike. It has also brought up other issues related to complementary areas of reform and integration to the forefront of theory and policy analysis. These issues shape the discussion about monetary union and, more generally, an optimal regime choice for countries in other regions, including North and Latin American and the Carribean.

The European Monetary Union stimulated a renewed interest in the design, implementation and transmission of monetary and fiscal policy in the European Union. A successful design and implementation of the common monetary policy by the European Central Bank (ECB) requires a detailed knowledge of the transmission mechanisms of the monetary policy. Also fiscal policy adjustments and their effects have played a crucial role in the EMU context as the fiscal convergence criteria stipulated in the Maastricht Treaty formed an important incentive for EU countries to improve their fiscal balances. A large number of countries have made fiscal policy adjustments and as a result they have made progress on fiscal consolidation and implemented various reforms of government spending and taxation. See Bas van Aarle, H. Garretsen and N. Gobbin (2003), Hoppner (2000), and Reutter and Westermann (2000), Monticelli and Tristani (1999), Ehrmann (2000), M. Ciccarelli and A. Rebucci (2005), See Kose, Meredith and Towe (2004), Hufbauer and Vega-Canovas (2003), Easterly, Fiess and Lederman (2003), Fiess and Fugazza (2002), Ramirez (2003), Lederman, Maloney and Luis (2003).

The introduction of the North America Trade Agreement (NAFTA) between the United States, Canada and Mexico has been received by some as the beginning of an economic union similar to the European. See N. Fiess and M. Fugazza (2002) for a review of the theoretical and empirical evidence relevant to the NAFTA integration experience. See also, D. Lederman, W. Maloney, and L. Serven (2003), C. Ciner (2006), M. Ramirez (2003), Pastor (2002). The economic union of south American countries has been also seen as a European Union-type. See C. 
Ghymers and C. Quenan (2005), A. Singh (2006), F. Mishkin and M. Savastro (2002), E. Dorruci, S. Firpo, M. Fratzscher, and F. P. Mongelli (2002), J. Zettelmeyer (2006).

This paper analyzes the macroeconomic effects of monetary and fiscal policies in the Euro-area and the NAFTA along with the non-NAFTA countries of the Americas using the structural VAR (SVAR) method. Shortrun and medium-run effects of monetary and fiscal policy innovations and demand and supply shocks are estimated. These effects are studied first at the EMU aggregate level. The effects of macroeconomic and macroeconomic policy shocks are estimated for the EMU-area. Theses effects are compared with those of the NAFTA and nonNAFTA countries. The estimation enables to analyze the important aspect of monetary and fiscal policy interaction and to analyze the relations between government revenue and government spending policies. In the final step, attention is also devoted to the role of financial markets in the transmission of macroeconomic and macroeconomic policy shocks.

The paper also estimates the response of individual EMU countries to macroeconomic and macroeconomic policy shocks and the results are compared again with the individual American countries. The paper contributes to the literature on monetary and fiscal policy analysis by integrating the literature on monetary SVARs and that on fiscal SVARs into one framework in which both are analyzed. This research also compares the results of these models with the American economies to show whether similarities or differences exist among monetary and fiscal policies. Comparisons suggest what policies towards integration may be adopted.

\section{LITERATURE REVIEW}

Several studies have used the Structural Vector Autoregressive models, to analyze the transmission mechanism of fiscal and monetary policy. Blanchard and Perotti (1999) and Fatas and Mihov (1999) use the SVAR method to identify the dynamic effects of shocks in government spending and taxes on the US economy in the post war period. Garcia and Verdelham (1999), study the fiscal and monetary policy transmission mechanism by identifying supply shocks, nominal shocks, fiscal and monetary policy shocks in the aggregate Euro-area economy. Dalsgaard and de Serres (2000) used a four variable SVAR model with real output growth, inflation, change of private sector savings, and the ratio of government net lending to GDP in 11 countries. Also Hoppner (2000), and Reutter and Westermann (2000) study the transmission of fiscal policy in France and Germany. Monticelli and Tristani (1999) use a SVAR model of the aggregate EMU-area to study the transmission of aggregate demand, aggregate supply and monetary policy innovations. Ehrmann (2000), compares monetary policy transmissions across EU countries using the VAR approach. Bas van Aarle, H. Garretsen and N. Gobbin (2003), study the channels of the transmission of monetary and fiscal policy in the EMU area countries and the effects on shocks on financial markets.

For the south American countries there has also been a vast amount of research. C. Ghymers and C. Quenan (2005), presents an analysis of the most recent trends surrounding the macroeconomic dynamics and its implications for regional integration in the countries of Latin America and the Carribean. A. Singh (2006), argues that Latin America generally compares unfavorably with other regions (such as Europe) and other developing areas (such as East Asia) in its ability to sustain significantly growth over prolonged periods. The same paper presents evidence of substantial cyclical co-movement along these countries. F. Mishkin and M. Savastro (2002) examine three possible monetary policy strategies for Latin American emerging markets. The paper concludes that in these emerging economies monetary policy cannot stand alone. Rigorous prudential supervision and sound fiscal policy are essential to the success of any monetary policy strategy. E. Dorruci, S. Firpo, M. Fratzscher, and F. P. Mongelli (2002), compares the economic integration of South American countries o the European Union. This research paper finds that Latin American countries compare to Europe lack of persistent fiscal discipline, low trade and financial integration and modest business cycle synchronization. J. Zettelmeyer (2006) is a summary of facts and about growth in Latin America, and shows how critical correlates have evolved over time. C. Calderon, and C. Schmidt-Hebbel (2003), use regression analysis to show that monetary and fiscal policies could be countercyclical in Latin American countries, with low to moderate country specific risks.. They conclude that the cyclical stance depends on country fundamentals and policy credibility. 


\section{MONETARY AND FISCAL POLICY ANALYSIS USING SVARs}

Structural Vector Autoregressive (SVAR) models originate from monetary policy analysis where it has been used extensively to study the transmission of real and monetary shocks. Structural VAR models impose identifying restrictions on an ordinary VAR model to infer structural shocks from it. Its workings can be briefly summarized as follows. Assume that the unrestricted VAR model, $X_{t}=A(L) e_{t}, \quad(1)$, is estimated - written in moving average form- where $\mathrm{x}$ is a vector of covariance stationary (macroeconomic) variables, $\mathrm{A}(\mathrm{L})$ a polynomial matrix of lag length $\mathrm{l}, \mathrm{L}$ is the lag operator and e a vector of reduced-form innovations in the elements of $\mathrm{x}$ with variance-covariance matrix $\mathrm{E}\left(\mathrm{e}_{\mathrm{t}} \mathrm{e}_{\mathrm{t}}^{\mathrm{T}}\right)=\sum$. These reduced form innovations are likely to be correlated and can, therefore not necessarily be interpreted as purely structural innovations. To correct this problem, the Structural Vector Autoregressive (SVAR) method which relates the vector $\mathrm{x}$ to a vector of structural innovations, $\mathrm{u}_{\mathrm{t}}$, is used.

Let $x=B(L) u_{t}$, (2), where $B(L)$ is a polynomial matrix in L. In this SVAR $u_{t}$ is a vector of serially and contemporaneously uncorrelated, normalized structural residuals with $E\left(u_{t} u_{t}^{T}\right)=I$. From (1) and (2) it follows that the vector of reduced -form innovations can be represented as a linear combination of the structural residuals, i.e. $e_{t}$ $=\mathrm{Cu}_{\mathrm{t}}$ with $\mathrm{CC}^{\mathrm{T}}=\Sigma$. As a result, $\mathrm{x}_{\mathrm{t}}=\mathrm{A}(\mathrm{L}) \mathrm{Cu}_{\mathrm{t}}=\mathrm{C}(\mathrm{L}) \mathrm{u}_{\mathrm{t}}$ and $\mathrm{A}(\mathrm{L}) \mathrm{C}=\mathrm{B}(\mathrm{L})$, enabling the identification of the structural innovations from the reduced-form innovations and the reduced form VAR. $C(L)$ is a lag polynomial where the Cs are coefficient matrices at the respective lags of the errors. In this way the structural form (2) can be obtain from the estimates of the reduced form representation (1), provided that the transformation matrix $\mathrm{C}$ is of full rank.

The structural VAR model (2) imposes identifying restrictions upon VAR estimates (1) to recover structural innovations from the estimated VAR. The identification is achieved by imposing short and long-run restrictions. The advantage of using long-run restrictions is that in many instances, economic theory provides more guidance about long-run restrictions than about short-run dynamics. Short restrictions impose typically that the impact effect of a given shock on a certain variable is null, which can be achieved by setting the appropriate elements in $\mathrm{C}(0)$ to zero. Long-run constraints impose typically that there is no long-run effect of a shock on a variable, which is achieved by setting the appropriate elements of $\mathrm{C}(1)$ to zero. In order to identify exactly a VAR model of $n$ endogenous variables, $\left(n^{2}-n\right) / 2$ restrictions need to be imposed in the structural model (2).

The SVAR method is particularly suited to asses the effects of fiscal and monetary policy innovations, since it isolates the response of each variable to structural shocks and policy innovations and shows their macroeconomic transmissions over time. The advantage of this approach is that there is no need to build a structural model describing the economy in general and the mechanisms of fiscal and monetary policy design and transmission in particular. The SVAR method only requires a minimum number of restrictions. Moreover, like a standard VAR model, the SVAR delivers two convenient tools in the form of impulse -response functions and variance decompositions that give much information on the impact and transmission of macroeconomic shocks and policy innovations.

The SVAR method used in this paper, was pioneered by Blanchard (1989) and Blanchard and Quah (1989)who concentrated on long-run identifying restrictions in identifying demand and supply shocks in the economy. Building upon these two papers Gali (1992) proposes a set of identifying restrictions that contains a combination of short and long-term restrictions. Bayoumi and Eichengreen (1992) use the SVAR method to identify aggregate demand and supply shocks in the EU and to assess to what extend the EU countries constitute an optimal currency area by distinguishing between symmetric and asymmetric shocks.

\section{EMPIRICAL ANALYIS OF THE TRANSMISSION OF MONETARY AND FISCLA POLICY USING THE SVAR METHOD}

In this study we use a five variable structural VAR model to discuss the transmission of monetary and fiscal policy mechanisms. The form of the five-variable model is as follows: $X_{t}=\sum_{i=1}^{n} A_{i} X_{t-i}+u_{t} \quad$ (4), where $\mathrm{X}=(\mathrm{Y}, \mathrm{T}, \mathrm{G}, \mathrm{I}, \mathrm{P})$ : : the vector of variables used in the model, $\mathrm{Y}=$ real output, $\mathrm{T}=$ real government revenue, $\mathrm{G}=$ real government spending, $\mathrm{I}=$ short term interest rates, and $\mathrm{P}=$ prices, $\mathrm{u}=\left(\mathrm{u}_{\mathrm{Y}}, \mathrm{u}_{\mathrm{T}}, \mathrm{u}_{\mathrm{G}}, \mathrm{u}_{\mathrm{I}}, \mathrm{u}_{\mathrm{P}}\right)$ the vector of the structural 
disturbances which are defined as: $\mathrm{E}\left(\mathrm{u}_{\mathrm{t}} \mathrm{u}_{\tau}{ }^{\prime}\right)=\mathrm{D}$ if $\mathrm{t}=\tau,=0$ otherwise. Rearranging terms in equation (4) we get: $\mathrm{X}_{\mathrm{t}}=\sum_{\mathrm{i}=1}^{\infty}\left(\mathrm{I}-\mathrm{A}_{0}\right)^{-1} \mathrm{~A}_{\mathrm{i}} \mathrm{X}_{\mathrm{t}-\mathrm{i}}+\left(\mathrm{I}-\mathrm{A}_{0}\right)^{-1} \mathrm{u}_{\mathrm{t}}$ or $\mathrm{X}_{\mathrm{t}}=\sum_{\mathrm{i}=1}^{\infty} \mathrm{G}_{\mathrm{i}} \mathrm{X}_{\mathrm{t}-\mathrm{i}}+\epsilon_{\mathrm{t}}(5), \mathrm{E}\left(\in_{\mathrm{t}} \in_{\mathrm{t}}^{\prime}\right)=\Omega$

if $\mathrm{t}=\tau,=0$ otherwise, where: $\mathrm{G}=\left(\mathrm{I}-\mathrm{A}_{0}\right)^{-1} \mathrm{~A}_{\mathrm{i}}$ and $\Omega=\left[\left(\mathrm{I}-\mathrm{A}_{0}\right)^{-1}\right] \mathrm{D}\left[\left(\mathrm{I}-\mathrm{A}_{0}\right)^{-1}\right]$,

Equation (4) is the reduced form VAR, and $\in=\left(\epsilon^{\mathrm{y}}, \epsilon^{\mathrm{T}}, \in^{\mathrm{G}}, \in^{\mathrm{I}}, \in^{\mathrm{P}}\right)$, is the vector of the reduced form residuals. From (4) and (5) it is easy to see that $\epsilon_{\mathrm{t}}=\left(\mathrm{I}-\mathrm{A}_{0}\right)^{-1} \mathrm{u}_{\mathrm{t}}$, so $\epsilon_{\mathrm{t}}=\mathrm{A}_{0} \in_{\mathrm{t}}+\mathrm{u}_{\mathrm{t}}(6)$. Assume equation (6) has the specific matrix form

$$
\left(\begin{array}{l}
\varepsilon^{y_{t}} \\
\varepsilon^{T_{t}} \\
\varepsilon^{G_{t}} \\
\varepsilon^{I_{t}} \\
\varepsilon^{P_{t}}
\end{array}\right)=\left(\begin{array}{l}
000 \\
\alpha 000 \\
\beta \gamma 00 \\
\delta \eta \theta 00 \\
\zeta \sigma \psi \omega 0
\end{array}\right)\left(\begin{array}{l}
\varepsilon^{y_{t}} \\
\varepsilon^{T_{t}} \\
\varepsilon^{G_{t}} \\
\varepsilon^{I_{t}} \\
\varepsilon^{P_{t}}
\end{array}\right)+\left(\begin{array}{l}
u^{S_{t}} \\
u^{T_{t}} \\
u^{G_{t}} \\
u^{I_{t}} \\
u^{P_{t}}
\end{array}\right)
$$

Since this is a recursive system, we can use the Choleski decomposition and recover the structural disturbance u's from the reduced form residuals $\in$ 's. From equation (5) we have $\Omega=\mathrm{E}\left(\in_{\mathrm{t}} \in_{\tau}{ }^{\prime}\right)=\left[\left(\mathrm{I}-\mathrm{A}_{0}\right)^{-1}\right] \mathrm{D}\left[\left(\mathrm{I}-\mathrm{A}_{0}\right)^{-1}\right]^{\prime}$, where $\Omega$ is the covariance matrix of the reduced form residual, D is the covariance matrix of the structural disturbance. Assuming $\mathrm{D}$ is diagonal, a need to estimate ten coefficients in $\mathrm{A}_{0}, \alpha, \beta, \gamma, \delta, \theta, \eta, \zeta, \sigma, \psi$, and $\omega$ and ten variances in $\mathrm{D}$ from $\Omega$. Since $\Omega$ has $10(10+1) / 2$ distinguished elements, the model is just identified.

\section{IV.1 Justification of the model:}

The VAR part estimates a reduced-form model of output, government revenue, and government spending, interest rates, and prices. The VAR estimations for the interest rates, government revenues, and government spending equations could be interpreted as systematic or automatic or anticipated monetary and fiscal policy responses to the endogenous variables in the VAR (these can also be interpreted as policy rules).

In other words, the estimated relations between the endogenous variables included in the VAR model, determine how the identified structural shocks are transmitted into the model. The structural component of the model identifies five structural disturbances, shown in (4). The structural monetary, the government revenue and government spending shocks represent unanticipated fiscal and monetary policy innovations.

The identification of the structural innovations require10 identifying restrictions:1)real government revenue shocks have only temporary effects on real output. 2) real government spending shocks have only temporary effects on real output. 3)real government spending shocks do not have a permanent effect on real government revenue. 4) monetary shocks do not have a permanent effect on real output. 5) monetary shocks do not have a permanent effect on real government revenue. 6)monetary do not have a permanent effect on real government spending. 7)demand shocks do not have a permanent effect on real output. 8)demand shocks do not have a permanent effect on real government revenue. 9)demand shocks do not have a permanent effect on real government spending. 10)demand shocks do not have a permanent effect on the interest rate.

Working hypotheses: 1) monetary shocks have a positive effect on $\mathrm{Y}$ and $\mathrm{P}$ 2) AD shocks have positive effects on $\mathrm{Y}$ and $\mathrm{P}$ in the short term 3) positive AS shocks have positive effects on $\mathrm{Y}$ but negative on $\mathrm{P}$ in short term but no effect on real output in the long term. 4) importance of AD shocks decreases over time. 5) importance of AS shocks for $\mathrm{Y}$ decreases over time. 6) monetary shocks are mostly responsible for $\mathrm{P}$ in the long-run. 7) government spending has a positive effect on output in the short term. 8) government revenue reduces output in the short term but has no effect in the log term.9) monetary shocks increase output but decrease interest rates in the short term. These restrictions can be discerned from the ordering of our variables in our VAR models. 
The database consists of time series of quarterly data for the period 1980:Q1 to 2004:Q4 for the Euro-area, north and south American countries and Japan from 1980:1-2004:2, whenever available. The data were provided by ECONSTATS and the IMF statistics.

All variables have been tested for unit roots and cointegration (tests are available upon request). All variables after transformations are stationary. Real variables have been adjusted for the inflation rate. The variables used for the final analysis are: growth rate of real output, RGDP, growth rate of real money supply, RMG, and the inflation rate INF, real government spending growth, real government revenue growth and the change in the shortterm interest rate. Using the Tiao and Box and the maximum likelihood method up to four lags are included in the estimation of all VAR models. Unit root tests are available upon request.

\section{EMPIRICAL RESULTS}

\section{V.1 Impulse Response Functions}

From the estimated SVAR models, impulse response functions and variance decompositions can be estimated which show the effects of supply, demand, and macroeconomic policy innovations on output, government revenue, government spending, interest rates, and inflation. In this section SVARS of monetary and fiscal policy of the EMU-countries as an aggregate are estimated and compared with the NAFTA countries, estimated also as an aggregate. Then the EMU economy is compared with the U.S. and Japan. Table 1 provides the estimated impulse response functions for the EMU economy, the Americas (US, Canada, Mexico, Brazil, Argentina, Chile) and Japan.

The graphs in the figures in table 1 show the accumulated effects on the endogenous variables in the VAR model- the quarterly growth rates of output, real government spending, real government revenue, nominal interest rates and prices. The figures show the accumulated responses of output $\mathrm{Y}$ and the price $\mathrm{P}$ to a positive shock in aggregate demand, a shock in aggregate supply and a positive shock in the growth rate of the money supply, a shock in taxes and a shock of government spending. The vertical axis in these figures denotes the level of real output or the level of price; the horizontal axis denotes time in quarters. These IRF's are cumulative, so they are the dynamic responses of the level of real output to one standard deviation of each shock in the time period of forty quarters. The slope of the IRF's therefore, indicate the output growth rate and the inflation rate. If the specification and identification of the model is correct, the impulse response functions will conform to the predictions of the theory.

Based on economic theory we expect: 1) A positive aggregate demand shock raises output and the price level 2) A positive aggregate supply raises output but decreases prices3) A shock in the money growth raises output and prices4) A positive shock in government spending raises output and prices.5) A positive shock in government revenue reduces output and prices. If the estimated IRF's are consistent with theses relationships, our identification assumptions will prove to have been plausible. Then we can use the IRF's to investigate the experience of the our analysis is suggestive of consensus of macroeconomic view. Based on theses consensus we would also expect:1) A positive aggregate demand to raise $\mathrm{Y}$ and $\mathrm{P}$ only temporarily (i.e. output growth and the inflation rate remain unaffected in the long-run).2) A positive aggregate supply shock to also affect $\mathrm{Y}$ and the growth rate of $\mathrm{P}$ temporarily.3) A positive shock in the money growth to raise output and output growth temporarily, but the price level and the inflation rate permanently.4) A positive government spending shock increases output and prices only temporarily5) A positive revenue (taxes) shock reduces output and prices only temporarily.

\section{V.2 Discussion of the implications of the IRF's:}

1) The effects of a positive aggregate demand shock

In the figures of table 1, we see that a positive aggregate demand shock moves output and prices in the same direction as predicted by the traditional AD-AS model. The increase in the level of output appears to be stable and permanent. After 5 quarters output will increase by about 4\%. The slope of the IRF of real output is getting flatter in the long-run, which means the growth rate of output increases only temporarily. While this is true for the 
EMU economy the US, Canada and Japan, that is not the case for Mexico. A positive AD shock eventually increases the price level. There two puzzles in the price level responses in fig.1: one is that after the shock in the inflation rate decreases for up to 5 quarters, it then increases in the price level became higher than the original level after more than 6 more quarters; the other puzzle is that in the usual AD-AS model, a positive demand shock raises the price level, and not the inflation rate, but here we see that after 6 quarters both the price level and the inflation rate keep increasing. In the case of US and Japan the output effect shocks seem to be smaller and more short-lived than in the Euro area.

\section{2) The effects of aggregate supply}

An AS shock moves output in the opposite directions. As predicted by theories, output increases but only in the short-run, after 4 quarters output starts falling to its long-term level. Since the IRF is getting flatter, the growth rate of output increases only temporarily. The price level decreases as output increases. In the first ten quarter prices increase by about $1.8 \%$. The inflation rate first increases, then starts to decrease after 6 quarters. Price level peaks after a few quarters then slowly decreases. (US, Japan, Canada and the Euro-area.) It seems that the effects of AD and AS shocks are more comparable in the US, Japan Canada and the EMU area than the rest of the Americas.

3) The effects of a positive shock in the monetary policy

Monetary policy innovations cause a small positive effect of interest rates in output that becomes negative after 2 quarters in US, Mexico, and Canada but that is non-existed in the EMU economy. The interest rate effect seems to increase prices in all countries but in the EMU area prices fluctuate at negative levels. This last result is in line with many other studies on the monetary transmission mechanism (known as the price puzzle) and leaves considerable doubt about the effectiveness of interest rate policies to control inflation. This however, is not true for the EMU area.

4) The effects of fiscal policy shocks are small of size and more diverse. Output does not increase due to an increase in government spending in the all economies. An increase in taxes does not reduce output in the EMU area. This can probably be explained by effects that outweigh the effects of Keynesian economics (see Giavazzi and Pagano 1996, and van Aarle and Garretsen 2001).

Overall the IRF's are consistent with mainstream views about macro-fluctuations that all the three shocks affect output and price. All the hypotheses of this study are supported by the analysis.

The results of the SVAR model allows us to discuss empirically, the interaction of fiscal and monetary policy issues within the EMU, NAFTA, and Latin American economies. The analysis of policy interactions has focused on the complementarity and substitutability of fiscal and monetary policy (see Melitz, 2000). In the first case a restrictive monetary policy is accompanied by a restrictive fiscal policy and vice versa. In the second case a restrictive monetary policy is accompanied by an expansionary fiscal policy and vice versa. In our analysis these interactions are measured by the impact of monetary shocks on the fiscal variables and the impact of fiscal shocks on the interest rate. It is shown in the figures of table 1, that -although the effects are rather small- in Japan, Mexico, Argentina, and Brazil monetary and fiscal policies do not interact. However, in the EMU area, US and Canada there is some complementarity as interest rates rise after a tax increase (see Bas van Aarle, Harry Garretsen and Niko Gobbin (2003) for a similar analysis with some contradictions). Monetary and fiscal policy act as complements in the EU since government spending decreases after a restrictive monetary policy shock. In the US, innovations in government spending do not affect interest rates. In Japan the spending increases after a restrictive monetary policy innovation.

The issue of the interdependency between spending and taxes can also be discussed with our VAR analysis we present here. The literature is concerned with the existence of causality between of any causality between spending and taxes. The causality and exogeneity issue has been phrased as the "tax and spend", where changes in taxes cause changes in tax revenues, versus the "spend and tax" view, where changes in government spending 
induce adjustments in taxes in order to much the changes in the financing needs. Blachard and Perotti (1999) and Fatas and Mihov (1999) investigate the effects of both types of causality by imposing the proper identifying restrictions on revenue and spending shocks in both regimes in their fiscal VAR model. Koren and Stiassy (1998), Garcia and Henin (1999) and De Archangelis and Lamartina (2001) also look at the possible links between taxes and spending.

Table 1 (available from author) provides information regarding the interaction between taxes and government spending. In the US, Japan, Argentina, Brazil and Canada, an increase in taxes increases government spending, while in the EU taxes increase first but then they become negative. An increase in taxes however, increase spending in Argentina, US, EU, Canada and Japan, but not in Mexico. This analysis, at first glance, would support the tax and spend hypothesis over the spend and tax hypothesis. Note however, that the effects of such policies are only short term. Therefore, there is no clear causality between taxes and spending in the US.

\section{VARIANCE DECOMPOSITIONS}

Variance decompositions are used to show the relative importance of the shocks in explaining the variability of the dependent variable $\mathrm{Y}$ in the model.

Based on generally accepted theories, we would expect that: 1) output variability is explained mainly by aggregate demand shocks in the short-run but in the long-run it is mainly explained by AS shocks. 2) both AD and AS shocks affect inflation variability in the short-run, but in the long-run inflation is a monetary phenomenon. (Variance decomposition results are available upon request).

\section{SUMMARY OF EMPIRICAL EVIDENCE}

\section{VII.1 General Results-Policy Implications}

The transmission of monetary and fiscal policy is a very important issue in the analysis of macroeconomic policy in the EMU, NAFTA and Latin American economies. This research paper used SVAR model to analyze the transmission of monetary and fiscal policy in the afformentioned economies. This model allowed to trace the effects of structural aggregate supply and demand and macroeconomic policy innovations on real prices, output, interest rates, and fiscal balances. The main conclusion of the empirical results is that: 1) on the level of the EMU-area the estimated adjustments are comparable to U.S., Canada, and Japan, 2) on the level of Latin American countries however, there is a diversity of results across countries. This paper suggests that fiscal rules in monetary unions may be necessary for the success of a monetary union. (This suggestion has been debated in the literature).

\section{AUTHOR INFORMATION}

Dimitrios Tsoukalas is a professor of Financial Economics at Purdue University. He teaches Advanced Statistics in the MBA program, Econometrics and Money and Banking and Real Estate Finance in the undergraduate program. Professor Tsoukalas received his Ph.D. form the University of Illinois in 1995. His noumerous publications appear in referee Journals such as the Global Finance Review, the Journal of Economic Perspectives and others.

\section{REFERENCES}

1. Albelola E., and Montero J.M., Debt Sustainability and Procyclical Fiscal Policis in Latin America, Working Paper No. 0611, Banco De Espania, 2006.

2. Bayoumi, T., and Eichengreen, B. (1992). Shocking aspects of the European monetary integration. In F. Torres and F. Giavazzi (Eds), Ajustment and growth in the European monetary union. (pp 193-229). Cambridge: Cambridge University Press

3. Bernanke and A. Blinder, The federal funds rate and the channels of monetary transmission. American Economic Review 824 (1992), pp. 901-921. 
4. Blachard, O., A traditional interpretation of macroeconomic fluctuations. American Economic Review 79 5, (1989), pp. 1146-1164.

5. Blachard O., and Perotti, R., An empirical characterization of the dynamic effects of changes in government spending and taxes on output (NBER working paper No. 7269)

6. Blachard, O., and Quah, D., The dynamic effects of aggregate supply and demand shocks. American Ecomic Review 794 (1989)

7. Caldero C., and Schidt-Hebbel K., Macroeconomic Policies and performance in Latin America, Journal of International Money and Finance, Vo. 22, Issue 7, December 2003, pp.895-923.

8. Ciccarelli M., and Rebucci A., Has the transmission mechanism OF European monetary policy changed in the run-up to EMU?, European Economic Review, 2005.

9. $\quad$ Ciner C., A further look at the linkages between NAFTA equity markets, The Quarterly Review of Economics and Finance, Vol. 46, Issue 3, July 2006, pp. 338-352

10. Dalsgaard, T. and A. de Serres, Estimating prudent budgetary margins for EU countries: A simulated SVAR model approach. OECD Economic Studies 301 (2001), pp.115-147.

11. De Arcangelis, G. and Lamartina, S., Fiscal and policy regimes in some OECD countries, mimeo ((2001).

12. Dorrucci E., Fibro S., Fratzsher M., and Mongelli F. P., European Integration: What Lessons For Other Reggions? The Case of Latin America, Working Paper No 185, October 2002.

13. Erhmann M., Comparing monetary policy transmission across European countries. Weltwirtschaftliches Archiv 1361 (2000), pp. 58-83.

14. Fatas, , A. and Mihov, I., The macroeconomic effects of fiscal policy, mimeo (1999).

15. Fiess N., and Fugazza M., European Integration: Review of the Literature and lessons for NAFTA Working Paper, September, 2002.

16. Gali J., How well does the IS-LM model fit post-war U.S. data. Quarterly Journal of Economics 107, (1992), pp. 975-1009)

17. Garcia, S. and Vardelhan, A., Impact of the monetary and fiscal shocks in the Euro-area, mimeo (1999).

18. Garcia, S. and P. Henin, Balancing budget through tax increases or expenditure cuts: Is it neutral? Economic Modeling 16, (199) pp. 591-612.

19. Giavazzi F. and M. Pagano, Non-Keynesian effects of fiscal policy changes: International evidence and the Swedish experience. Swedish Economic Review 3, pp. 69-103 (1996).

20. Hochreiter E., K. Schmidt-Hebbel, and G. Winckler, Monetary Union: European Lessons, Latin American Prospects, North American Journal of Economics and Finance, 13, 2002.

21. Koren S. and A.Stiassny, Tax and spend, or spend and tax? An international study. Journal of Policy Modeling 202 (1998), pp. 163-191.

22. Lederman D., W. Maloney, and L. Serven, Lessons from NAFTA for Latin America and the Carribean Countries: A Summary of Research Findings, Office of the chief economist for LAC, The World Bank, December, 2003.

23. Mishkin S. F., and Svastro M. A., Monetary Policy Strategies for Emarging Market Countries: Lessons From Latin America, Working Paper, Draft: January 2002.

24. Monticelli, C. and Tristani, O. What does the single monetary policy do? A SVAR Benchmark for the European Central Bank (1999), (European Bank Working Paper Series No. 2).

25. Ramirez M., Mexico under NAFTA:a critical assessment, The Quarterly Review of Economics and Finance, Vol. 43, Issue 5, Winter 2003, pp. 863-892

26. Singh A., Macroeconomic Volatility: The Policy Lessons from Latin America, IMF Working PAper, WP/06/166, Revised August, 2006.

27. van Aarle, B. and Garretsen, H. Keynesian, non-Keynsian or nom effects of fiscal policy changes? The EMU case (CESifo Working Per No. 570). Munich (2001)001,

28. Zettlmeyer J., Growth and Reforms in Latin America: A Survey of Facts and Arguments, IMF Working Paper, WP/06/210, IMF 2006. 